\title{
Effects of Several Physicochemical Factors on the Biodegradation of 1,4-Dioxane by Microbial Consortium CDIK-3 Enriched from Industrial Wastewater
}

\author{
Moon-Seop Choi ${ }^{1,2} \cdot$ Ki-Seung Choi ${ }^{2} \cdot$ Kye-Heon Oh ${ }^{1,+\oplus}$ \\ 'Department of Life Science and Biotechnology, Soonchunhyang University \\ ${ }^{2} \mathrm{CDI}$ Co., Ltd
}

(Received June 17, 2020; Revised July 14, 2020; Accepted July 22, 2020)

Objective: With the ultimate aim of application for effluent treatment, the relationships between 1,4-dioxane degradation by microbial consortium CDIK-3 and several relevant physicochemical environmental parameters were investigated.

Methods: Microbial consortium CDIK-3 enriched from an industrial wastewater sample developed to grow aerobically with 1,4-dioxane as the sole carbon substrate was used to evaluate the degradation of 1,4-dioxane depending on the various environmental parameters and HPLC methodology was used to measure residual 1,4-dioxane in the test consortium.

Results and Discussion: The microbial consortium, designated CDIK-3, was originally enriched from industrial wastewater sample. Complete depletion of $1,000 \mathrm{mg} / \mathrm{L} \mathrm{1,4-dioxane} \mathrm{was} \mathrm{achieved} \mathrm{in} \mathrm{this} \mathrm{experiment} \mathrm{within} 168 \mathrm{~h}$. Effective 1,4-dioxane degradation was observed in slightly alkaline conditions ( $\mathrm{pH} 8$ ) and $30^{\circ} \mathrm{C}$. The effect of supplemented carbon and nitrogen (e.g., glucose, yeast extract, ethylene glycol, tetrahydrofuran) on the 1,4-dioxane degradation by the CDIK-3 test culture was evaluated. The results indicated that the addition of glucose, yeast extract, or tetrahydrofuran accelerated bacterial growth compared to growth in the absence of supplemented carbons. In contrast, the addition of low concentrations $(\leq 100 \mathrm{mg} / \mathrm{L})$ of ethylene glycol accelerated 1,4-dioxane degradation, but the degradation of 1,4-dioxane was delayed in the culture to which high concentrations ( $\geq 200$ $\mathrm{mg} / \mathrm{L}$ ) of ethylene glycol were added.

Conclusions: 1,4-Dioxane as a wastewater contaminant can be removed by the microbial consortium CDIK-3 enriched from industrial wastewater. Effective 1,4-dioxane removal was obtained by the control of various physicochemical parameters. These results provide clues for understanding improved 1,4-dioxane degradation by microbial consortium CDIK-3 with relevant environmental parameters and possible applications in the processing of industrial wastewater containing relatively high 1,4-dioxane concentrations.

Keywords: 1,4-Dioxane, Microbial Consortium CDIK-3, Biodegradation, Industrial Wastewater

The Korean text of this paper can be translated into multiple languages on the website of http://jksee.or.kr through Google Translator. 


\title{
연구논문
}

\section{산업폐수에서 농화한 미생물컨소시엄 CDIK-3에 의한 1,4-dioxane의 생분해에 영향을 미치는 물리화학적 요인}

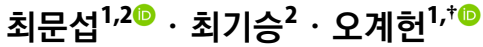 \\ ${ }^{1}$ 순천향대학교 자연과학대학 생명시스템학과 \\ ${ }^{2}$ (주) 씨디아이
}

목적: 폐수처리에 적용하기 위한 궁극적인 목표를 가지고, 미생물컨소시엄 CDIK-3에 의한 1,4-dioxane 분해와 여 러 가지 관련 물리화학적 환경요인들과의 관계를 조사하였다.

재료 및 방법: 1,4-Dioxane을 유일한 탄소원으로 사용하여 호기적 조건에서 생장할 수 있는 미생물컨소시엄 CDIK-3를 산업폐수로부터 농화를 통해 확보하였다. 여러 가지 환경요인에 따른 1,4-dioxane의 분해를 평가하였으 며, HPLC를 사용하여 1,4-dioxane의 농도를 측정하였다.

결과 및 토의: CDIK-3로 지정된 미생물컨소시엄은 원래 산업폐수로부터 농화되었다. $1,000 \mathrm{mg} / \mathrm{L}$ 의 1,4-dioxane은 168 시간 이내에 완전히 분해되었으며, 효율적인 1,4-dioxane 분해는 약알칼리성 $(\mathrm{pH} 8)$ 과 $30^{\circ} \mathrm{C}$ 에서 각각 관찰되었 다. CDIK-3의 배양에서 1,4-dioxane 분해에 영향을 미치는 부가탄소원 및 질소원(예, glucose, yeast extract, ethylene glycol, tetrahydrofuran)의 효과를 조사하였다. 그 결과, glucose, yeast extract, 또는 tetrahydrofuran의 첨가 는 부가탄소원을 첨가하지 않은 것과 비교하여, 1,4-dioxane의 분해를 향상되었다. 반면에 ethylene glycol은 저농도 $(\leq 100 \mathrm{mg} / \mathrm{L})$ 에서 1,4-dioxane 분해가 향상되었으나, 고농도 $(\geq 200 \mathrm{mg} / \mathrm{L})$ 가 첨가된 경우에는 $1,4-$ dioxane 분해가 지연되었다.

결론 : 폐수오염물질인 1,4-dioxane은 산업폐수로부터 농화된 미생물컨소시엄 CDIK-3에 의해 제거될 수 있다. 다양 한 물리화학적 요인의 조절을 통하여 효율적인 1,4-dioxane의 제거가 이루어졌다. 이러한 결과는 적절한 환경요인 들 하에서 배양된 미생물컨소시엄 CDIK-3에 의해 1,4-dioxane 분해가 향상되는 것을 이해하는데 단서를 제공하며, 상대적으로 고농도의 1,4-dioxane을 포함하는 산업폐수의 처리에 적용될 수 있다.

주제어: 1,4-Dioxane, 미생물컨소시엄 CDIK-3, 생분해, 산업폐수

\section{1. 서 론}

급속한 산업의 발달로 사용되는 유기 화학물질의 종류가 다양해지는 것뿐만 아니라, 이들 화학물질의 사용량도 매년 크게 증가하고 있다. 이에 따른 환경오염 문제도 증가하고 있으며, 특히 산업체에서 방류되는 산업폐수로 인한 수질 오염 문제가 지속적으로 제기되고 있다. ${ }^{1)}$ 1,4-Dioxane은 최 근 수계에서 주목받고 있는 오염물질로서, 염소계 용매의 안정제와 광택제, 코팅제, 접착제 등의 원료인 cellulose acetate, ethyl cellulose, benzyl cellulose를 용해시키는 용매 로서 뿐만 아니라, ${ }^{2,3)}$ 화장품, 의약품 제조, 고무화학 등 여 러 산업 분야에서 용매로 사용되며, ${ }^{4,5}$ 폴리에스터(polyester) 및 계면활성제 등의 제조 공정에서 부산물로 생성된다. ${ }^{6,7)}$ 1,4-Dioxane의 배출량은 매년 증가하고 있으며, 국내에서
2017년 기준으로 연간 약 2.5톤이 산업폐수에 포함되어 방 류되었다고 보고되었다. ${ }^{1)}$ 1,4-Dioxane은 화학적으로 안정한 고리형 에테르 화합물로 물에 쉽게 용해되며, 가연성 화학 물질로서 빛에 장기간 노출 시 폭발성의 peroxides를 형성 할 수 있다. ${ }^{8)}$ 토양, 유기물 등에 잘 흡착되지 않기 때문에 인근 하천이나 지하수로 쉽게 유입될 수 있으며, 하천과 지 하수 등으로 유입된 1,4-dioxane은 광범위한 지역에서 오염 원이 될 수 있다고 알려져 있다.,10)

국제 암연구기관(International Agency for Research on Cancer)에서는 쥐의 비강암과 간암 및 기니피그의 담낭암의 증가사례를 바탕으로 1,4-dioxane을 인간에서 발암 가능성이 있는 물질인 Group 2B로 분류하고 있다. ${ }^{11}$ 1,4-Dioxane은 인 간과 동물에서 눈과 호흡기에 질병을 유발하고, 고농도의 1,4-dioxane에 노출 시 단시간에 신장과 간에 심각한 손상을 
유발하며, 직업적으로 피부와 점막에 노출되거나 흡입한 사 람들에서 신장에 문제를 일으키는 것으로 보고되었다. ${ }^{12)}$

현재 1,4-dioxane은 대부분 화학적 방법으로 처리되고 있 다. 특히 고도산화공정(advanced oxidation process, AOP)은 1,4-dioxane을 비교적 효과적으로 처리하는 것으로 보고되고 있으나, 이러한 공정은 큰 규모의 기반시설이 필요하며, 추 가적인 2 차 처리와 높은 처리비용 및 2 차 오염 등의 문제가 제기되는 것으로 알려져 있다. ${ }^{13-16)}$ 최근 환경친화적인 방법 으로 미생물을 이용한 1,4-dioxane의 제거에 대한 연구가 발표되고 있다. 1,4-Dioxane을 분해할 수 있는 미생물로서, Pseudonocardia sp., Acinetobacter sp., Mycobacterium sp., Flavobacterium sp., Rhodococcus sp., Cordyceps sp. 등이 환 경으로부터 분리되었으며, ${ }^{17-23)}$ 이들을 이용한 1,4-dioxane 생 분해에 관련된 연구가 보고되었다. 그러나 지금까지 발표된 1,4-dioxane 생분해에 관한 연구는 주로 단일배양을 이용하 여, 1,4-dioxane을 분해할 수 있는 미생물 자원의 확보 또는 생화학 및 유전학적 현상을 규명하는 연구에 국한되어 왔다. 일부 연구에서 지하수, 산업 폐수, 토양 등에서 1,4-dioxane 을 분해할 수 있는 미생물컨소시엄을 확보하여, ${ }^{24-26)}$ 이들을 1,4-dioxane 제거에 적용하려는 시도를 보고하였다. 미생물 컨소시엄에는 1,4-dioxane의 분해에 직접 관여하는 미생물뿐 만 아니라, 1,4-dioxane 분해를 개시하거나, 중간대사산물을 분해하여 1,4-dioxane 분해를 보조해주는 미생물들이 공존하 기 때문에 단일배양보다 효율적일 수 있다. ${ }^{27)}$ 그러나 실제 산업체에서 배출되는 고농도의 1,4-dioxane이 포함된 폐수를 처리하거나, 실제 현장(in situ)에 적용을 위한 연구는 상대적 으로 미미한 실정이다.

1,4-Dioxane의 미생물학적 제거에 있어서 환경적 요인 들이 이 화학물질의 분해에 영향을 미친다는 연구결과들 이 발표되어왔다. 온도, $\mathrm{pH}$ 등의 환경적 요인이 변화함에 따라 1,4-dioxane 분해능이 향상되었으며, ${ }^{22)}$ yeast extract, tetrahydrofuran, 1-butanol, root extract 등의 부가물질을 첨 가함으로써 1,4-dioxane 분해능이 증진된다는 결과들이 보 고된 바 있다. ${ }^{19-23)}$

본 연구에서는 산업폐수로부터 1,4-dioxane을 분해할 수 있는 미생물컨소시엄 CDIK-3을 확보하여, 이 배양에서 여 러 가지 물리적 요인(예, 기질 농도, $\mathrm{pH}$, 온도) 및 부가탄소 원 및 질소원(예, glucose, yeast extract, ethylene glycol, tetrahydrofuran)이 1,4-dioxane 분해에 미치는 영향을 비교 분석하였다.

\section{2. 재료 및 방법}

\section{1. 세균의 분리 및 배양}

울산 지역의 $\mathrm{S}$ 공단에서 채취한 폐수 표본으로부터 농화 배양 기법을 통하여 1,4-dioxane을 분해할 수 있는 3 개의 미
생물컨소시엄(CDIK-1, CDIK-2, CDIK-3)을 확보하였다. 사 용된 배지는 ammonium mineral salts (AMS)였으며, 증류수 1 L당 $0.66 \mathrm{~g}\left(\mathrm{NH}_{4}\right)_{2} \mathrm{SO}_{4}, 1.0 \mathrm{~g} \mathrm{MgSO}_{4} \cdot 7 \mathrm{H}_{2} \mathrm{O}, 0.015 \mathrm{~g}$ $\mathrm{CaCl}_{2} \cdot 2 \mathrm{H}_{2} 0,1.0 \mathrm{~mL}$ AMS trace elements(증류수 $1 \mathrm{~L}$ 당 0.5 g $\mathrm{FeSO}_{4} \bullet 7 \mathrm{H}_{2} 0,0.4 \mathrm{~g} \mathrm{ZnSO}_{4} \bullet 7 \mathrm{H}_{2} 0,0.02 \mathrm{~g} \mathrm{MnSO}_{4} \bullet \mathrm{H}_{2} 0$, $0.015 \mathrm{~g} \mathrm{H}_{3} \mathrm{BO}_{3}, 0.01 \mathrm{~g} \mathrm{NiCl}_{2} \bullet 6 \mathrm{H}_{2} 0,0.25 \mathrm{~g}$ EDTA, $0.05 \mathrm{~g}$ $\mathrm{CoCl}_{2} \cdot 6 \mathrm{H}_{2} 0,0.005 \mathrm{~g} \mathrm{CuCl}_{2} \cdot 2 \mathrm{H}_{2} 0$ ), $1 \mathrm{~mL}$ AMS stock $\mathrm{A}$ (증 류수 $1 \mathrm{~L}$ 당 $5.0 \mathrm{~g} \mathrm{Fe}-\mathrm{Na}$ EDTA, $2.0 \mathrm{~g} \mathrm{NaMoO}_{4} \cdot 2 \mathrm{H}_{2} \mathrm{O}$ ), 20.0

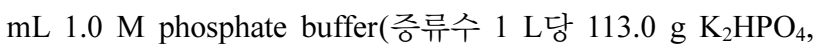
$47.0 \mathrm{~g} \mathrm{KH}_{2} \mathrm{PO}_{4}$ )를 포함하는 기본 배지에 단일 탄소원으로 1,4-dioxane $(250 \sim 1,500 \mathrm{mg} / \mathrm{L})$ 이 첨가된 배지를 사용하였다. 준비된 배지는 $\mathrm{pH} 7.0$ 으로 조절한 후 고압멸균하였으며, 폐 수를 접종 후 진탕배양기 $\left(25^{\circ} \mathrm{C}, 150 \mathrm{rpm}\right)$ 에서 호기적으로 배양하였다. 한 달 동안 7일 간격으로 농화 배양의 $10 \%$ $(\mathrm{v} / \mathrm{v})$ 를 신선한 AMS에 계대 배양하며, 1,4-dioxane 분해능 이 가장 우수한 미생물컨소시엄 CDIK-3을 본 연구에 사용 하였다.

\subsection{1,4-Dioxane의 분석}

1,4-Dioxane 농도를 측정하기 위하여 HPLC를 사용하였다. 분석에 사용된 HPLC system은 UV/Visible Detector 2489, Isocratic HPLC Pump 1515와 Autosampler 2707가 부착 된 Waters 사(Milford, MA, USA)의 HPLC였으며, 컬럼 은 Agilent 사(Santa Clara, CA, USA)의 Eclipse XDB-C18 $(4.6 \times 250 \mathrm{~mm}, 5 \mu \mathrm{m})$ 을 사용하였다. HPLC 작동조건으로 유속은 $1 \mathrm{~mL} / \mathrm{min}, \mathrm{UV}$ 파장은 $200 \mathrm{~nm}$ 로 설정하였으며, 이동 상(mobile phase)은 $12 \%$ acetonitrile을 $0.45 \mu \mathrm{m}$ membrane filter에 여과하고, 초음파세정기를 이용하여 용액 내의 기포 를 제거한 후 사용하였다. ${ }^{28)}$ 표준물질은 분석용 고순도 1,4-dioxane (Sigma Co., St. Louis, MO, USA)을 사용하였으 며, 분석 시료는 배양액을 $13,000 \mathrm{rpm}$ 에서 10 분간 원심분리 후, 상등액을 $0.45 \mu \mathrm{m}$ syringe filter로 여과하여 사용하였다.

\subsection{1,4-Dioxane 분해에 물리적 요인이 미치는 영향}

미생물컨소시엄 CDIK-3에서 물리적 요인으로서, 기질 농 도, $\mathrm{pH}$, 온도의 변화가 1,4-dioxane의 분해에 미치는 영향을 조사하였다.

1) 기질 농도: CDIK-3의 1,4-dioxane 분해에서 기질 농도 가 미치는 영향을 조사하였다. 기질로서 1,4-dioxane 농도에 따른 분해능을 비교하였으며, $250 \mathrm{mg} / \mathrm{L}, 500 \mathrm{mg} / \mathrm{L}, 750$ $\mathrm{mg} / \mathrm{L}, 1,000 \mathrm{mg} / \mathrm{L}, 1,250 \mathrm{mg} / \mathrm{L}, 1,500 \mathrm{mg} / \mathrm{L}$ 의 1,4-dioxane을 포함하는 각각의 배지에 $10 \%$ 의 CDIK-3을 접종하여 생장 및 1,4-dioxane 분해를 비교하였다.

2) $\mathrm{pH}$ : 1,4-Dioxane의 분해에 있어서 초기 $\mathrm{pH}$ 가 1,4-dioxane 분해에 미치는 영향을 비교하였다. $1,000 \mathrm{mg} / \mathrm{L}$ 의 1,4-dioxane 이 포함된 배지에 초기 $\mathrm{pH}$ 를 $1 \mathrm{~N} \mathrm{HCl}$ 과 $1 \mathrm{~N} \mathrm{NaOH}$ 를 사용하 
여, 각각 $6,7,8$, 또는 9로 조절된 배지에 $10 \%$ 의 CDIK-3을 접종하여 생장 및 1,4-dioxane 분해를 비교하였다.

3) 온도: 배양 온도에 따른 1,4-dioxane 분해능을 비교하 였다. $1,000 \mathrm{mg} / \mathrm{L}$ 의 1,4-dioxane이 포함된 배지에 $10 \%$ 의 $\mathrm{CDIK}-3$ 을 접종한 후, $20,25,30,35^{\circ} \mathrm{C}$ 에서 각각 배양하며, 생장 및 1,4-dioxane 분해를 비교하였다.

\section{4. 부가탄소원 및 질소원이 1,4-dioxane 분해에 미치는 영향}

미생물컨소시엄 CDIK-3에서 부가탄소원 및 질소원의 종류 와 농도에 따른 1,4-dioxane의 분해에 미치는 영향을 조사하 였다. 선택한 부가탄소원 및 질소원은 가장 보편적인 탄소원 으로 glucose, 질소원 및 탄소원으로 널리 알려진 yeast extract, 그리고 보통 난분해성 화합물들의 생분해에서 공동대사를 통 해 분해의 효율을 증진시키는 것으로 알려진 ethylene glycol 과 tetrahydrofuran을 선택하여 본 연구에 사용하였다. ${ }^{19-23)}$ 각 배지에 $\mathrm{CDIK}-3$ 을 접종한 후, 진탕배양기 $\left(30^{\circ} \mathrm{C}, 150 \mathrm{rpm}\right)$ 에서 배양하며, 생장과 1,4-dioxane 분해를 조사하였다.

1) Glucose: 1,4-Dioxane $(1,000 \mathrm{mg} / \mathrm{L})$ 이 포함된 배지에 glucose(각각 $0,10,20,30,40,50 \mathrm{mg} / \mathrm{L}$ )를 첨가하여 1,4-dioxane 분해에 미치는 영향을 조사하였다.

2) Yeast extract: 1,4-Dioxane $(1,000 \mathrm{mg} / \mathrm{L})$ 이 포함된 배지 에 yeast extract(각각 $0,10,20,30,40,50 \mathrm{mg} / \mathrm{L}$ )를 첨가하 여 1,4-dioxane 분해에 미치는 영향을 조사하였다.

3) Ethylene glycol: 1,4-Dioxane $(1,000 \mathrm{mg} / \mathrm{L})$ 이 포함된 배 지에 ethylene glycol(각각 $0,100,200,300 \mathrm{mg} / \mathrm{L}$ )을 첨가하 여 1,4-dioxane 분해에 미치는 영향을 조사하였다.

4) Tetrahydrofuran: 1,4-Dioxane $(1,000 \mathrm{mg} / \mathrm{L})$ 이 포함된 배지에 tetrahydrofuran(각각 $0,50,100,150,200 \mathrm{mg} / \mathrm{L}$ )을 첨가하여 1,4-dioxane 분해에 미치는 영향을 조사하였다.

\section{3. 결과 및 고찰}

\section{1. 미생물컨소시엄 CDIK-3의 분리 및 배양}

울산 지역에 있는 $\mathrm{S}$ 공단의 원수저장조, 침전조, 포기조의 3곳에서 폐수 시료를 채취하여, 농화배양 기법으로 1,4-dioxane 을 탄소원으로 이용하는 3 가지 미생물컨소시엄을 확보하였으 며, 각각 CDIK-1, CDIK-2, CDIK-3로 명명하였다. 이들 가운 데, CDIK-3는 1,4-dioxane의 분해능이 가장 우수한 컨소시엄 으로 조사되었으며, 연속적인 실험을 위하여 배양 중에 균주의 대수기를 식별하여 새로운 배지에 연속 계대배양한 후, 진탕배 양기 $\left(25^{\circ} \mathrm{C}, 150 \mathrm{rpm}\right)$ 에서 유지시키며, 생장 및 1,4-dioxane 분 해를 관찰하는데 사용하였다.

\section{2. 미생물컨소시엄 CDIK-3의 생장과 1,4-dioxane 분해}

미생물컨소시엄 CDIK-3에 의한 1,4-dioxane 분해와 미생
물 생장, 그리고 배양기간 중의 $\mathrm{pH}$ 변화를 관찰하였다. 배지 내의 1,4-dioxane의 농도는 $1,000 \mathrm{mg} / \mathrm{L}$ 였으며, 초기 $\mathrm{pH}$ 는 7.0이었다(Fig. 1). 배양 36시간부터 1,4-dioxane이 급격한 감 소가 시작되었으며, $1,000 \mathrm{mg} / \mathrm{L}$ 의 1,4-dioxane은 168 시간 이 내에 완전히 분해되었다. CDIK-3의 생장은 접종 후 36시간 부터 서서히 증가하기 시작하였으며, 144 시간부터 급격하게 생장하였다. 배양 기간 중에 $\mathrm{pH}$ 변화는 크게 변화가 없었는 데, 초기 7.0에서 서서히 감소되어, 배양 후 144 시간에 $\mathrm{pH}$ 6.9 로 가장 낮게 측정되었으며, 이후, $\mathrm{pH}$ 는 점차 증가하여 168 시간에 이르러 7.1 로 측정되었다. 배양 내의 잔존 1,4-dioxane은 HPLC로 분석하였으며, HPLC chromatogram 에서 1,4-dioxane의 retention time은 4.00 분에서 확인되었으 며, 별도의 주요 피크는 나타나지 않았다. 배양 후, 24시간마 다 채취한 시료에서의 잔존 1,4-dioxane의 peak 변화는 Fig. 2에서 보여주고 있다.

\subsection{1,4-Dioxane 분해에 물리화학적 요인이 미치는 영향}

\subsection{1. 기질 농도}

기질로서 초기 1,4-dioxane 농도에 따른 미생물컨소시엄 CDIK-3의 생장과 1,4-dioxane 분해에 미치는 영향을 관찰하 였다(Fig.3). 접종한 후 48시간이 경과하면서 뚜렷한 생장 이 관찰되었으며, $1,250 \mathrm{mg} / \mathrm{L}$ 와 $1,500 \mathrm{mg} / \mathrm{L}$ 의 1,4-dioxane 이 첨가된 배지에서 가장 높은 생장률을 나타내었다. 1,4-Dioxane 분해는 접종 후 36시간부터 1,4-dioxane 농도 가 서서히 감소하였으며, $250 \mathrm{mg} / \mathrm{L}, 500 \mathrm{mg} / \mathrm{L}, 750 \mathrm{mg} / \mathrm{L}$, $1,000 \mathrm{mg} / \mathrm{L}$ 의 1,4-dioxane은 각각 72시간, 96시간, 120 시간, 168 시간 이내에 완전히 분해되었다. 그러나 1,4-dioxane의

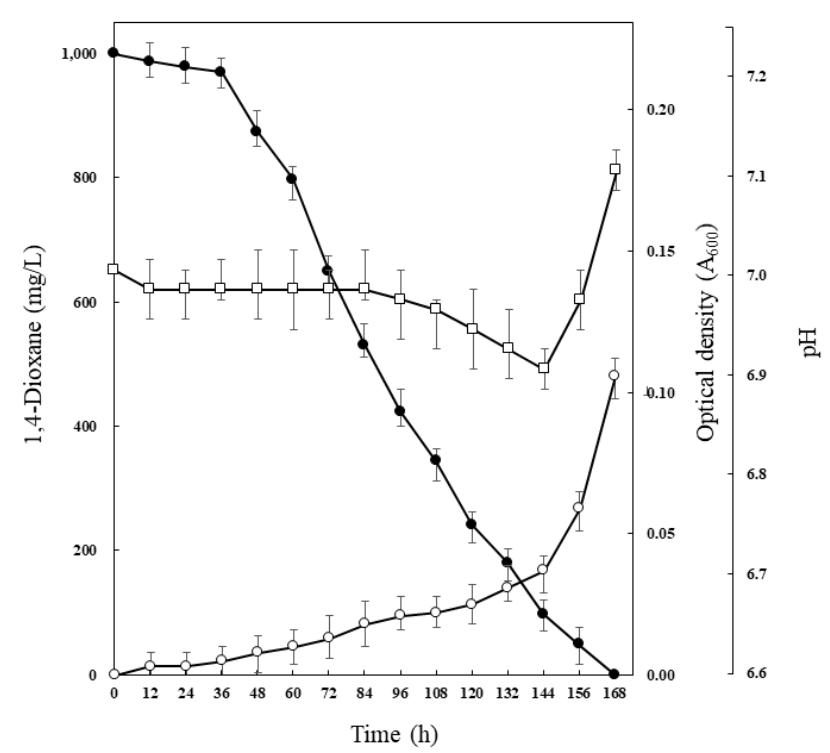

Fig. 1. Growth of microbial consortium CDIK-3, measured as cell density (O), $\mathrm{pH}(\square)$ and residual 1,4-dioxane (O). Error bars indicate the standard deviations of three replicates. 


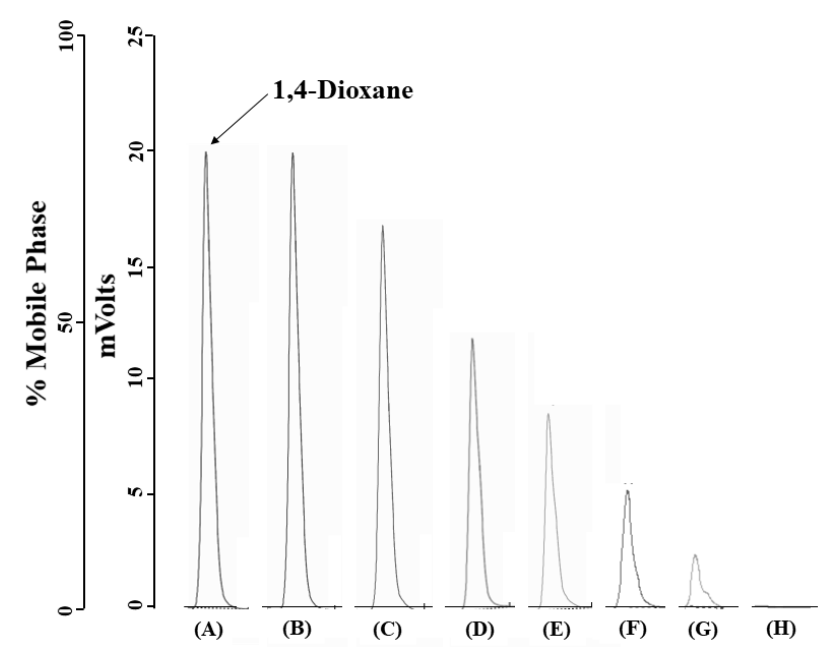

Fig. 2. HPLC chromatograms of culture samples initially (A), and after $24 \mathrm{~h}(\mathrm{~B}), 48 \mathrm{~h}(\mathrm{C}), 72 \mathrm{~h}(\mathrm{D}), 96 \mathrm{~h}(\mathrm{E}), 120$ $\mathrm{h}(\mathrm{F}), 144 \mathrm{~h} \mathrm{(G)}$, and $168 \mathrm{~h}(\mathrm{H})$ of incubation. Initial concentration of 1,4-dioxane was $1,000 \mathrm{mg} / \mathrm{L}$.

농도가 $1,250 \mathrm{mg} / \mathrm{L}$ 와 $1,500 \mathrm{mg} / \mathrm{L}$ 로 증가함에 따라, 주어진 배양기간인 168 시간 동안에 각각 $80 \%$ 와 $67 \%$ 의 부분적인 분해가 진행되었다. $\mathrm{Kim}$ 등 ${ }^{18}$ 이 분리한 Mycobacterium sp. PH-06은 15일 동안 $900 \mathrm{mg} / \mathrm{L}$ 의 1,4-dioxane을 분해하였으 며, Pugazhendi 등 ${ }^{20}$ 은 Rhodanobacter AYS5를 이용하여 10 일 동안 $950 \mathrm{mg} / \mathrm{L}$ 의 1,4-dioxane이 제거됨을 발표하였다.

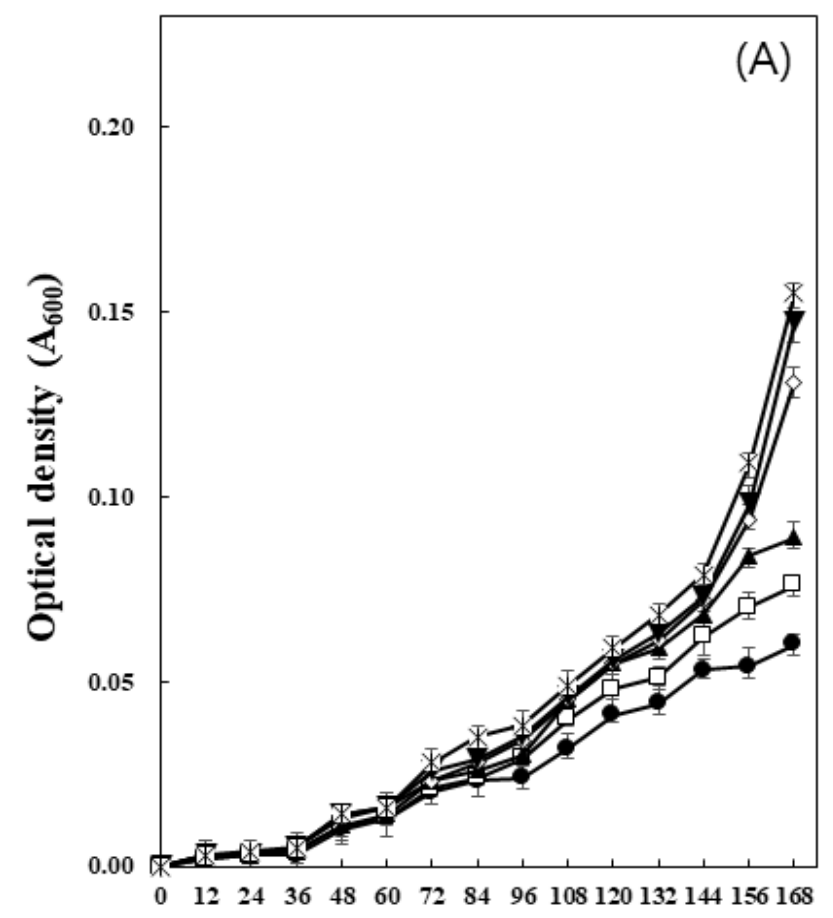

Time (h)
또한, Nakamiya 등 ${ }^{19)}$ 은 Cordyceps sp.을 이용한 연구에서 3 $\mathrm{mg} / \mathrm{L}$ 의 1,4-dioxane을 3 일 이내에 분해하였으며, Inoue 등 ${ }^{22)}$ 이 분리한 Rhodococcus aetherivorans JCM 14343은 $20 \mathrm{mg} / \mathrm{L}$ 1,4-dioxane을 약 30 시간 이내 분해한다고 보고한 바 있다. 이들 결과와 비교하여, 본 연구에서 분리한 CDIK-3은 250 $\mathrm{mg} / \mathrm{L}$ 의 1,4-dioxane을 72 시간 이내, 그리고 $1,000 \mathrm{mg} / \mathrm{L}$ 의 1,4-dioxane도 168 시간 이내에 완전히 분해하여, 기존에 발 표된 미생물들과 비교하여 1,4-dioxane의 분해능이 탁월한 것으로 판단된다.

\subsection{2. $\mathrm{pH}$}

미생물컨소시엄 CDIK-3을 이용하여 1,4-dioxane의 분해에 있어서 최적 $\mathrm{pH}$ 를 알아보기 위하여, 초기 $\mathrm{pH}$ 를 조절하여 분 해와 생장에 미치는 영향을 관찰하였다(Fig.4). 초기 $\mathrm{pH}$ 를 6.0 으로 조정하여 1,4-dioxane의 분해를 관찰한 결과 168 시 간 동안 약 $90 \%$ 의 분해를 나타내었다. 반면 초기 $\mathrm{pH} 7.0$ 과 8.0 의 경우에는 각각 168 시간, 144 시간 이내에 완전 분해를 보여주었으며, $\mathrm{pH} 9.0$ 인 경우에서도 약 $97 \%$ 의 분해를 나타 내었다. Inoue 등 22)이 분리한 Rhodococcus aetherivorans $\mathrm{JCM} 14343$ 은 $\mathrm{pH} 7.0$ 에서 $20 \mathrm{mg} / \mathrm{L}$ 의 1,4-dioxane을 48시간 이내 분해하였으며, $\mathrm{pH} 8.0$ 과 $\mathrm{pH}$ 9.0에서는 1,4-dioxane 분 해능이 약 $10 \%$ 감소하는 결과를 보고하였다. 그러나 본 연 구에서 분리한 CDIK-3은 생장과 1,4-dioxane 분해에 있어서

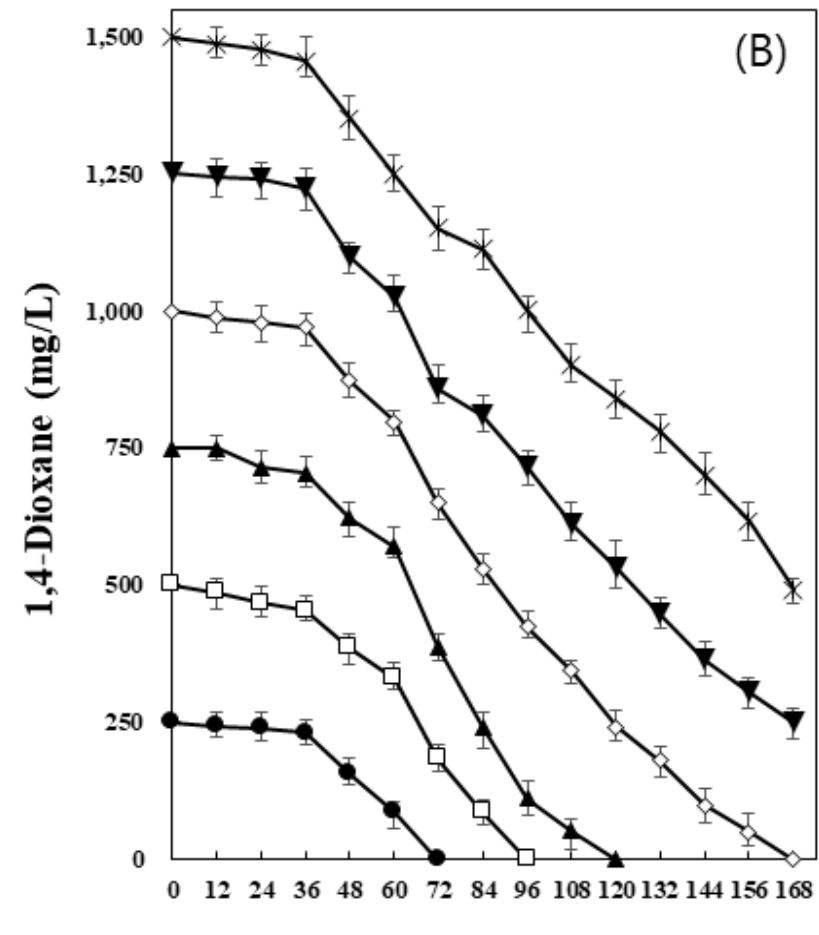

Time (h)

Fig. 3. Growth of the microbial consortium CDIK-3 (A) and the degradation of 1,4-dioxane (B) at different 1,4-dioxane concentrations. The media contained $250 \mathrm{mg} / \mathrm{L}(\bullet), 500 \mathrm{mg} / \mathrm{L}(\square), 750 \mathrm{mg} / \mathrm{L}(\mathbf{\Delta}), 1,000 \mathrm{mg} / \mathrm{L}(\diamond), 1,250 \mathrm{mg} / \mathrm{L}(\boldsymbol{\nabla})$, $1,500 \mathrm{mg} / \mathrm{L}(*)$ 1,4-dioxane, respectively. Error bars indicate the standard deviations of three replicates. 


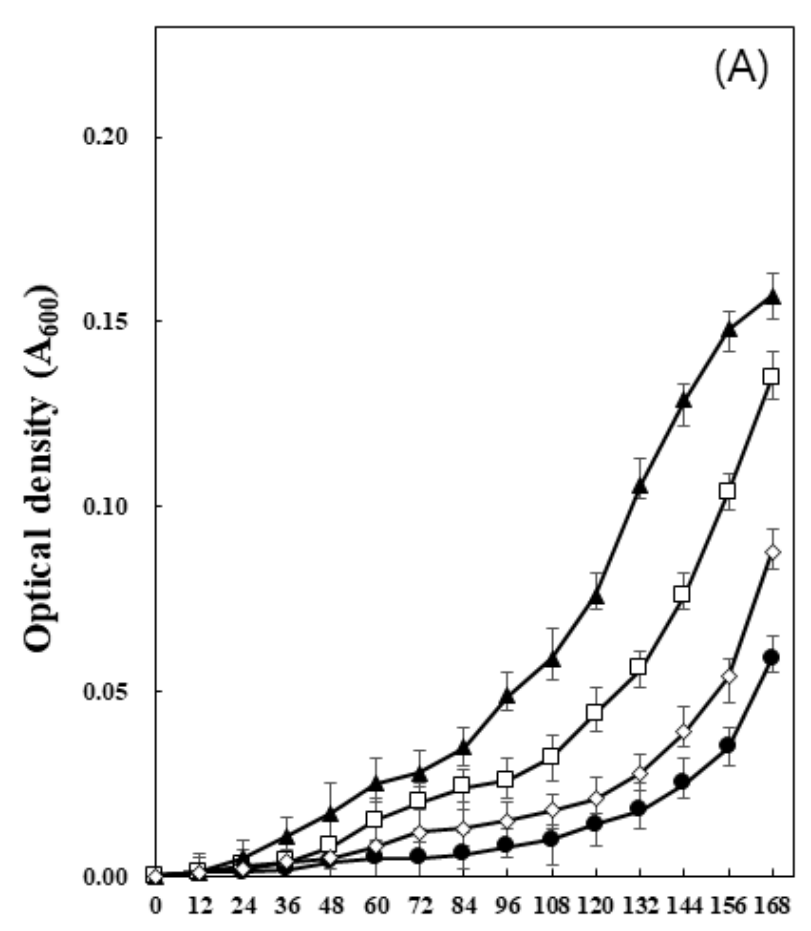

Time (h)

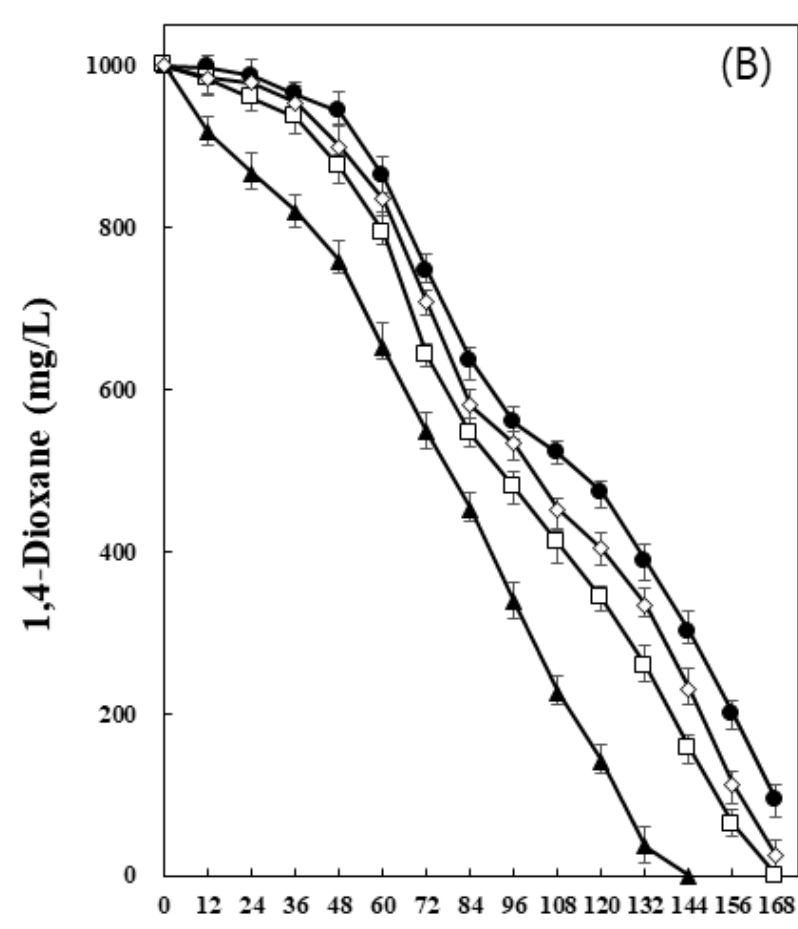

Time (h)

Fig. 4. Growth of the microbial consortium CDIK-3 (A) and the degradation of 1,4-dioxane (B) at different pHs. The media were adjusted at pH $6.0(\bullet), 7.0(\square), 8.0(\Delta), 9.0(\diamond)$, respectively. Initial concentration of 1,4-dioxane was 1,000 $\mathrm{mg} / \mathrm{L}$ 1,4-dioxane. Error bars indicate the standard deviations of three replicates.

$\mathrm{pH}$ 환경이 비교적 약산성보다는 약알칼리에서 적응 능력이 높았으며, 분해도 효과적인 것으로 분석되었다.

\subsection{3. 온도}

미생물컨소시엄 CDIK-3 배양이 1,4-dioxane 분해와 생장 에 미치는 최적 온도를 알아보기 위하여 본 실험을 수행하 였다(Fig. 5). 그 결과, 배양 온도가 $20^{\circ} \mathrm{C}$ 인 경우에 168 시간 동안 배지 내의 1,4-dioxane 중 약 $90 \%$ 가 분해되었으며, 생 장에서도 수행된 다른 온도와 비교하여 생장이 다소 저조한 것이 관찰되었다. $25^{\circ} \mathrm{C}$ 와 $35^{\circ} \mathrm{C}$ 에서는 각각 168 시간 이내에 완전히 제거되는 것으로 나타났으며, 특히 $30^{\circ} \mathrm{C}$ 에서 배양하 였을 경우 156 시간 이내에 완전히 분해되어, CDIK-3의 1,4-dioxane 분해에 있어서 최적 온도는 $30^{\circ} \mathrm{C}$ 로 조사되었다. Inoue 등 ${ }^{22}$ 이 분리한 Rhodococcus aetherivorans JCM 14343 의 경우 $28^{\circ} \mathrm{C}$ 에서 $20 \mathrm{mg} / \mathrm{L}$ 의 1,4-dioxane을 48 시간 이내 분 해하였으며, $20^{\circ} \mathrm{C}$ 와 $35^{\circ} \mathrm{C}$ 에서는 분해능이 약 $10 \%$ 감소하는 결과를 보고한 바 있는데, 이 결과는 본 연구에서 얻어진 결 과와 유사하였다.

\section{4. 부가탄소원 및 질소원의 첨가에 따른 생장 및 1,4-dioxane의 분해}

\subsubsection{Glucose}

부가탄소원으로서 glucose를 첨가하여 미생물컨소시엄
CDIK-3의 생장과 1,4-dioxane 분해에 미치는 영향을 조사하 였다(Fig. 6). Glucose가 첨가된 배지에서 생장은 증가하였 으며, 첨가된 glucose의 농도가 증가할수록 높은 생장률을 나타내었다. $10 \mathrm{mg} / \mathrm{L}$ 의 glucose가 첨가된 경우에, glucose를 첨가하지 않은 경우와 마찬가지로 1,4-dioxane은 144시간 이내에 완전 분해되는 동일한 결과가 나타났다. $20-50 \mathrm{mg} / \mathrm{L}$ 의 glucose를 첨가한 경우에서도 완전 분해 기간은 각각 132 시간 이내로, 첨가하지 않은 것과 비교하여 분해능은 다소 향상되었으나, 궁극적으로 첨가된 glucose의 농도에 따른 1,4-dioxane의 분해의 차이는 미미한 것으로 조사되었 다. 일부 과학자들은 부가탄소원으로서 glucose의 첨가가 1,4-dioxane의 분해를 저해시키는 결과를 가져오는 것으로 보고하였다. Pugazhendi 등 ${ }^{20}$ 은 Rhodanobacter AYS5를 이 용한 연구에서 $100 \mathrm{mg} / \mathrm{L}$ 의 1,4-dioxane에 glucose를 첨가한 경우, 분해능이 약 $40 \%$ 감소하였으며, Kelley 등 ${ }^{23)}$ 의 연구 에서도 glucose를 첨가함으로 $25 \mathrm{mg} / \mathrm{L}$ 의 1,4-dioxane이 완 전 분해되는데 소요되는 기간이 약 17 일에서 21 일로 지연 되면서 1,4-dioxane 분해능이 감소함을 보고한 바 있다. 그 러나 CDIK-3의 경우 glucose 첨가함으로써 1,4-dioxane 분 해능이 약 $10 \%$ 향상되었는데, 이는 CDIK-3 배양에 존재하 는 1,4-dioxane을 분해하는 미생물들이 먼저 glucose를 소비 하여 짧은 시간 내에 급격하게 생장하고 결국 이들에 의한 1,4-dioxane의 분해가 향상된 것으로 판단된다. 


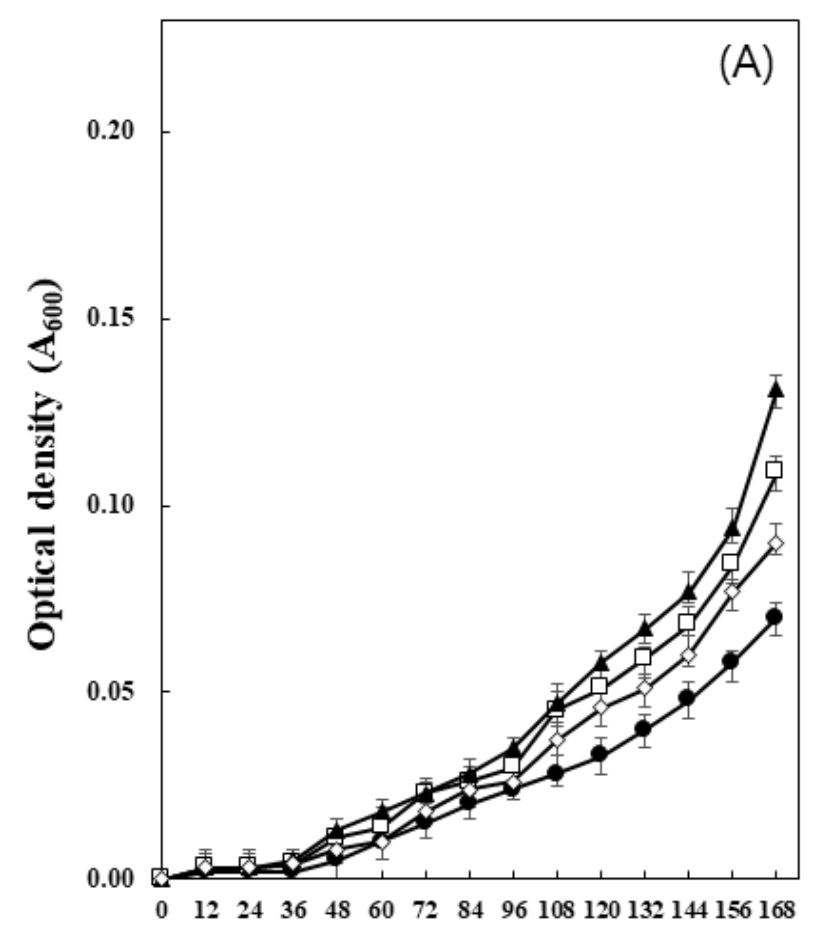

Time (h)

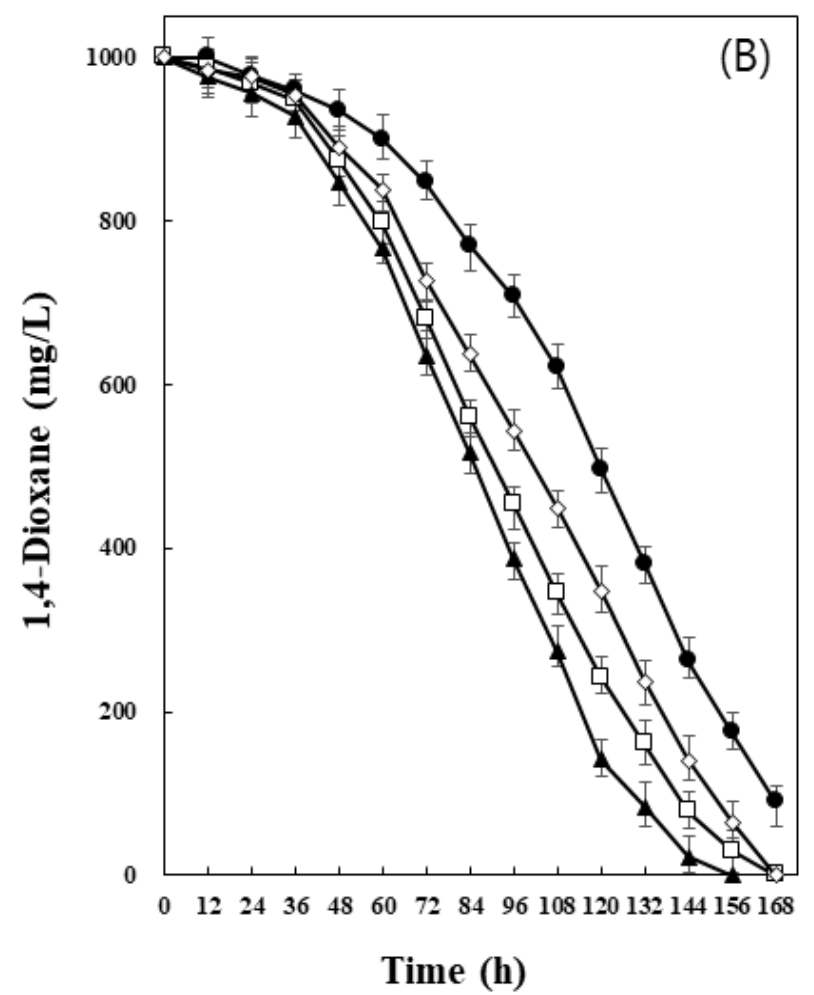

Fig. 5. Growth of the microbial consortium CDIK-3 (A) and the degradation of 1,4-dioxane (B) at different incubation temperature. The consortia were incubated at $20^{\circ} \mathrm{C}(\bullet), 25^{\circ} \mathrm{C}(\square), 30^{\circ} \mathrm{C}(\Delta), 35^{\circ} \mathrm{C}(\diamond)$, respectively. Initial concentration of 1,4-dioxane was $1,000 \mathrm{mg} / \mathrm{L}$ 1,4-dioxane. Error bars indicate the standard deviations of three replicates.

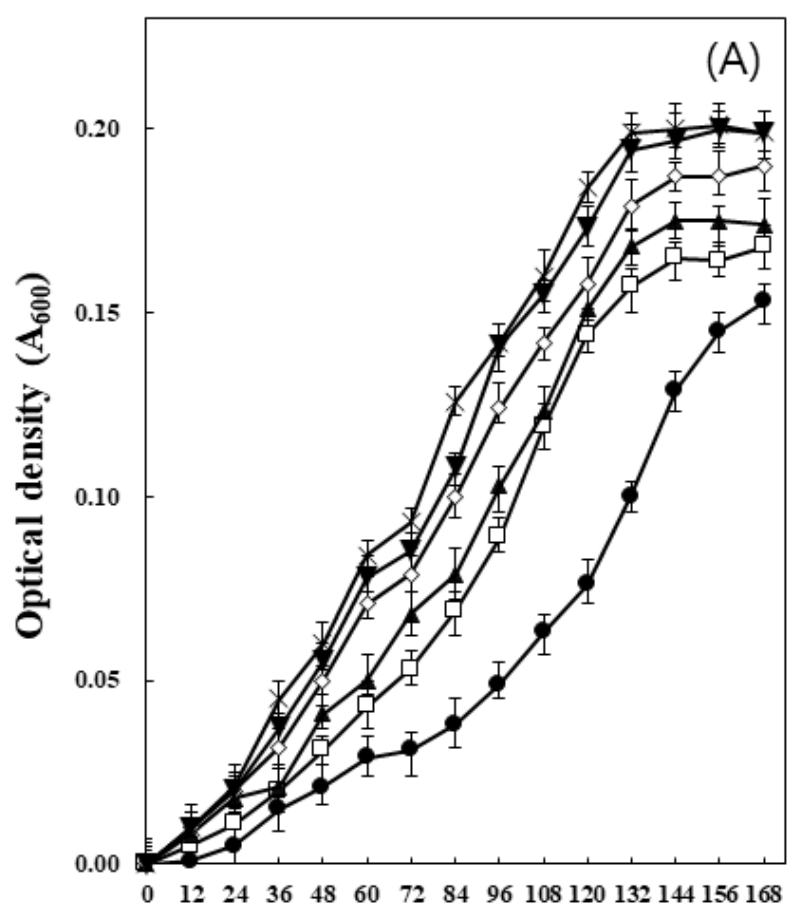

Time (h)

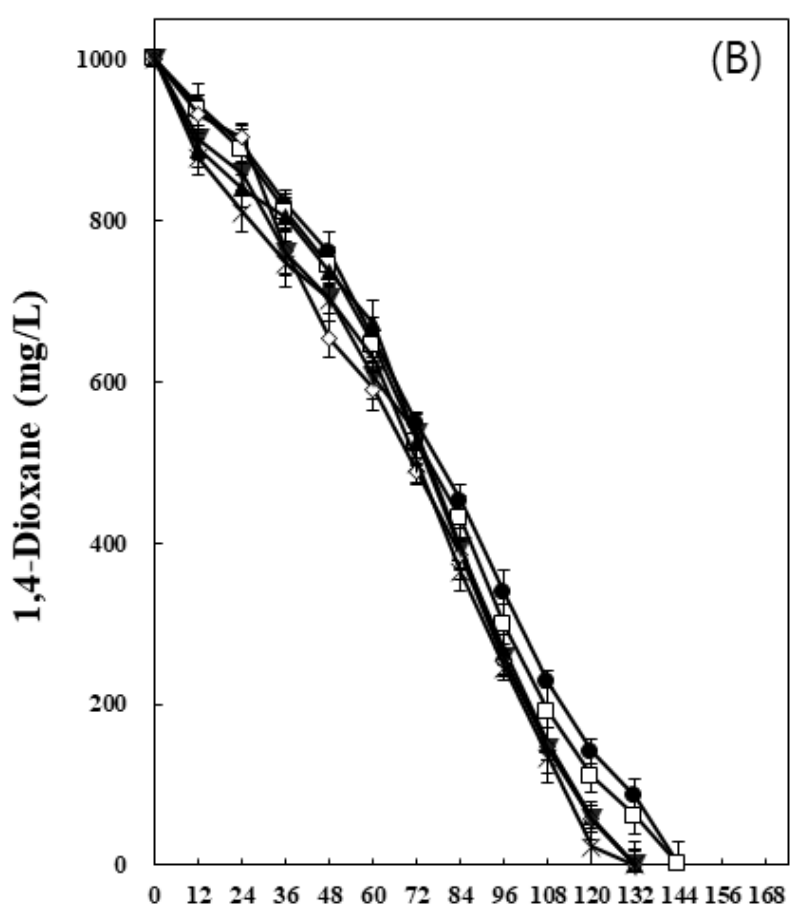

Time (h)

Fig. 6. Growth of microbial consortium CDIK-3 (A) and the degradation of 1,4-dioxane (B) in the presence of $0 \mathrm{mg} / \mathrm{L}(\mathbf{O}), 10$ $(\square), 20(\Delta), 30(\diamond), 40(\nabla), 50(*) \mathrm{mg} / \mathrm{L}$ of glucose as a supplemental carbon source. Initial concentration of 1,4-dioxane was $1,000 \mathrm{mg} / \mathrm{L}$ 1,4-dioxane. Error bars indicate the standard deviations of three replicates. 


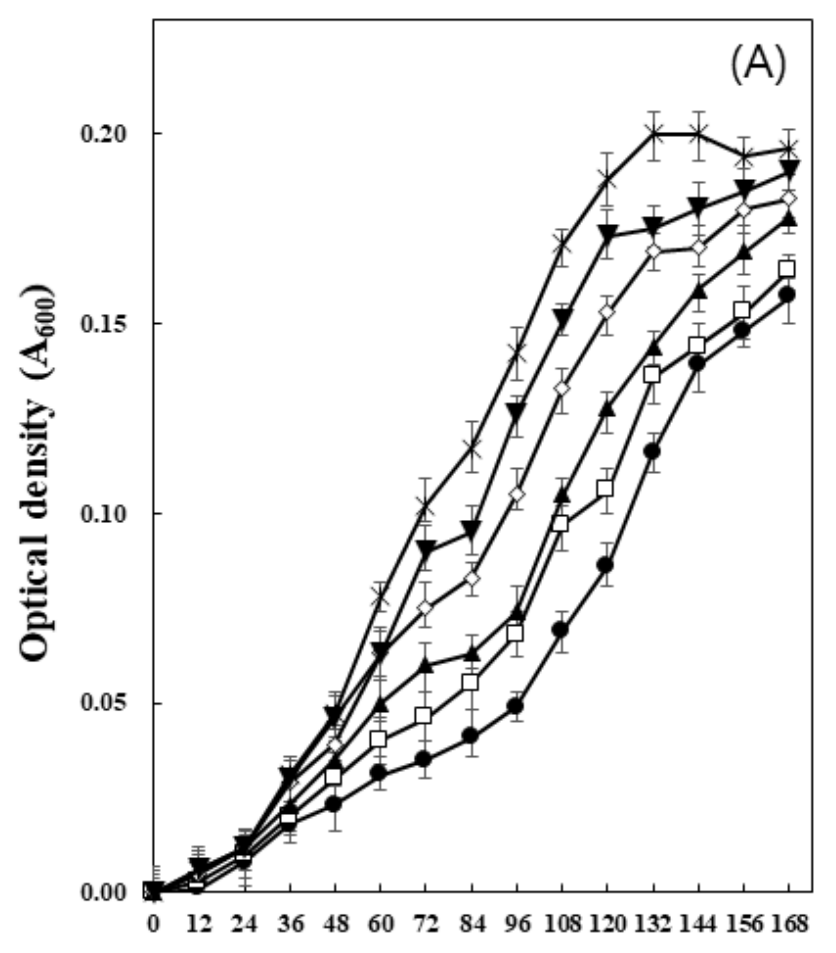

Time (h)

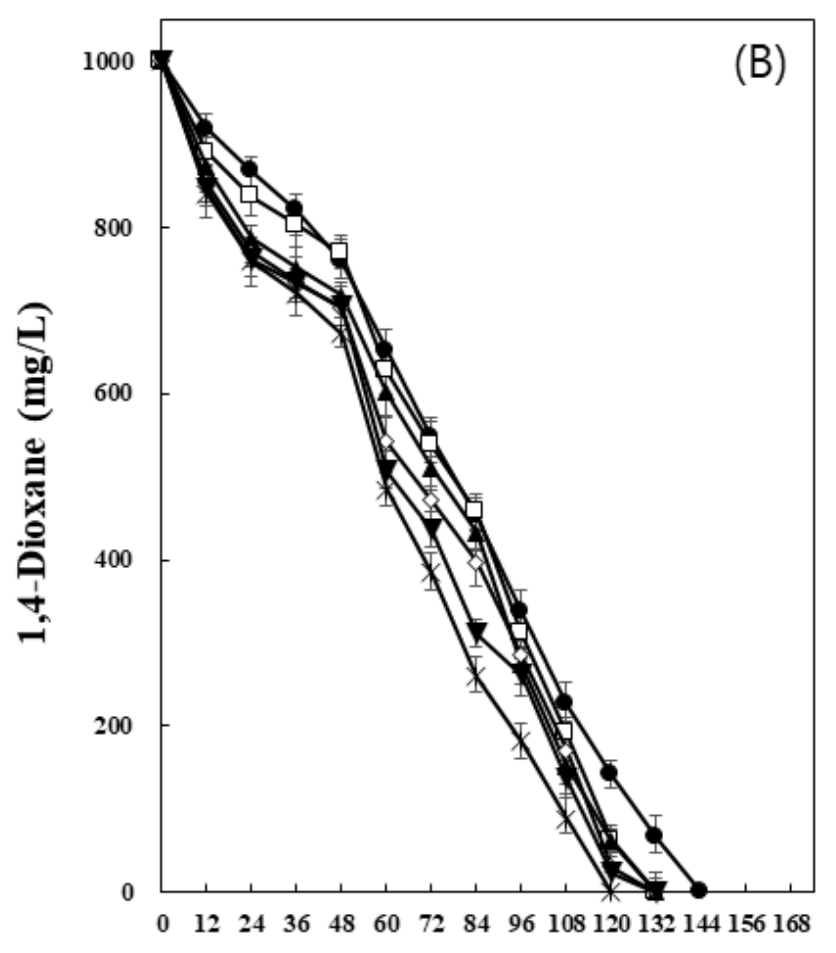

Time (h)

Fig. 7. Growth of microbial consortium CDIK-3 (A) and the degradation of 1,4-dioxane (B) in the presence of $0 \mathrm{mg} / \mathrm{L}(\mathrm{O}), 10$ $(\square), 20(\Delta), 30(\diamond), 40(\nabla), 50(*) \mathrm{mg} / \mathrm{L}$ of yeast extract as a supplemental nitrogen source. Initial concentration of 1,4-dioxane was $1,000 \mathrm{mg} / \mathrm{L} \mathrm{1,4-dioxane.} \mathrm{Error} \mathrm{bars} \mathrm{indicate} \mathrm{the} \mathrm{standard} \mathrm{deviations} \mathrm{of} \mathrm{three} \mathrm{replicates.}$

\subsubsection{Yeast extract}

미생물컨소시엄 CDIK-3 배양에 다른 농도의 yeast extract 를 첨가한 후, 생장과 1,4-dioxane 분해에 미치는 영향을 관찰하였다(Fig.7). Yeast extract를 첨가한 경우는 첨가 하지 않은 것과 비교하여 생장률이 급격히 증가하였으며, yeast extract의 농도가 증가할수록 높은 생장률을 나타내었 다. $10-40 \mathrm{mg} / \mathrm{L}$ 의 yeast extract가 첨가된 경우에 완전히 분해되는데 소요되는 시간은 모두 132시간 이내로 동일한 것으로 나타났으며, $50 \mathrm{mg} / \mathrm{L}$ 가 첨가된 경우는 120 시간 이 내에 완전 분해됨으로써 yeast extract를 첨가하지 않은 것 보다 1,4-dioxane 분해능이 크게 향상되었다. Pugazhendi 등 $^{20)}$ 은 Rhodanobacter AYS5 배양에 포함된 $1,000 \mathrm{mg} / \mathrm{L}$ 의 1,4-dioxane이 10 일 동안 약 $95 \%$ 를 분해되었으나, yeast extract가 첨가된 상태에서 배양 9 일 만에 완전히 분 해되었음을 보고하였다. Yeast extract에는 다양한 아미노 산과 펩타이드, 수용성 비타민, 탄수화물 등이 포함되어 있어 많은 미생물에서 우수한 기질로 사용되는데, 본 연구 에서 얻어진 결과는 CDIK-3이 이들 성분들을 생장인자로 이용할 뿐만 아니라, 포함된 질소원으로 인해 탄소-질소 비율 $(\mathrm{C} / \mathrm{N}$ ratio)을 변화시켜 대사활성을 증진시킴으로써 궁극적으로 생장과 1,4-dioxane 분해를 향상시키는 것으로 판단된다.

\subsubsection{Ethylene glycol}

미생물컨소시엄 CDIK-3 배양에서 ethylene glycol의 첨 가에 따른 생장과 1,4-dioxane 분해를 조사하였다(Fig. 8). Ethylene glycol을 첨가한 경우, 생장은 급격히 증가하였 으며, ethylene glycol의 농도가 증가할수록 높은 생장률 을 나타내었다. 1,4-Dioxane 분해는 $100 \mathrm{mg} / \mathrm{L}, 200 \mathrm{mg} / \mathrm{L}$, $300 \mathrm{mg} / \mathrm{L}$ 의 ethylene glycol을 첨가하였을 때, 배양 후 각 각 120 시간, 156 시간, 168 시간 이내에 완전히 분해되었으 나, 그 농도가 증가함에 따라 완전분해에 도달하는데 걸리 는 시간은 점차 늘어났다. Inoue 등 ${ }^{22}$ 은 ethylene glycol를 첨가함으로 1,4-dioxane 분해능은 첨가하지 않은 것과 비 교하여 약 $30 \%$ 가 감소하였으며, Nakamiya 등 ${ }^{19}$ 도 ethylene glycol이 1,4-dioxane 분해를 억제하는 것으로 보 고하였다. 그러나 본 연구에서 CDIK-3 배양의 1,4-dioxane 분해는 저농도 $(\leq 100 \mathrm{mg} / \mathrm{L})$ 의 ethylene glycol를 첨가한 경 우, 1,4-dioxane보다 이용이 용이한 ethylene glycol을 먼저 소비하여 짧은 시간 내에 급격하게 생장 및 분해가 진행되 었으며, ethylene glycol 농도 $(\geq 200 \mathrm{mg} / \mathrm{L})$ 가 증가함에 따 라 1,4-dioxane 분해는 점차 억제되는 것으로 나타났다. 배 양에서 ethylene glycol 첨가에 따른 미생물의 생장과 1,4-dioxane의 분해와의 상관관계는 연구가 필요할 것으로 사료된다. 


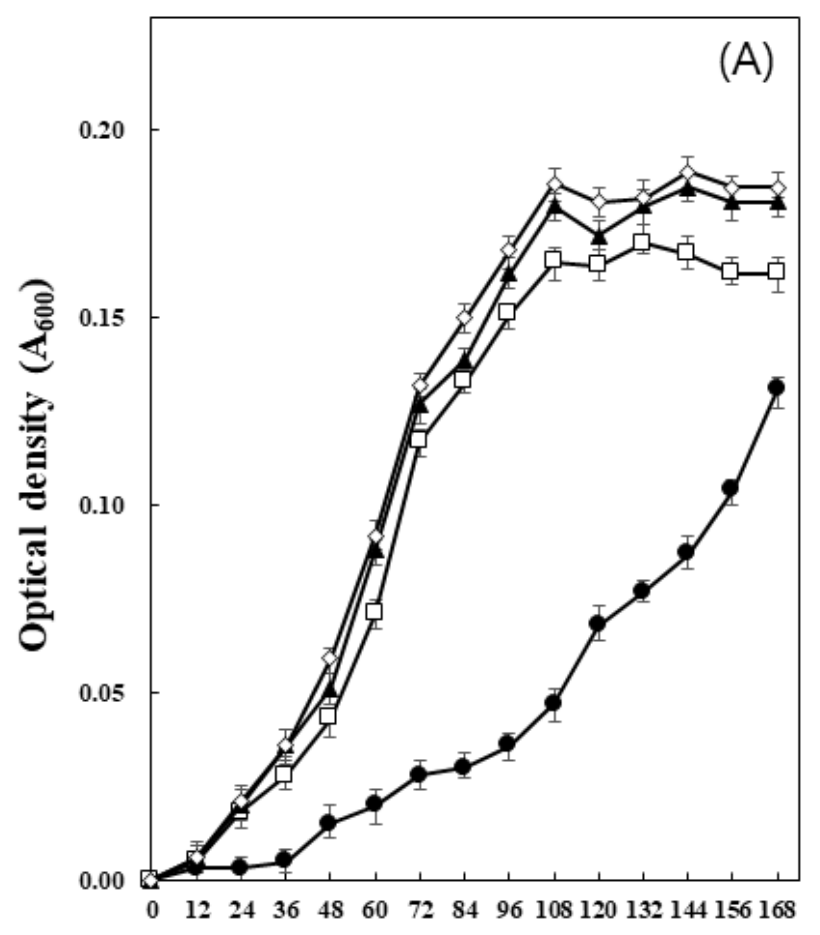

Time (h)

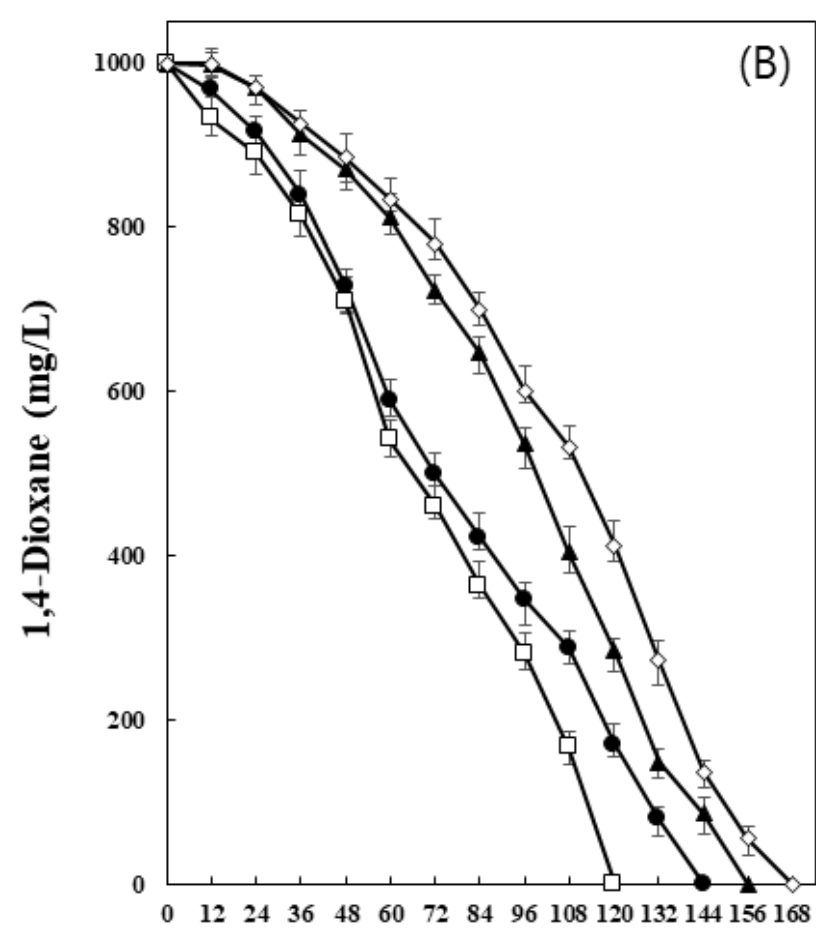

Time (h)

Fig. 8. Growth of microbial consortium CDIK-3 (A) and the degradation of 1,4-dioxane (B) in the presence of $0 \mathrm{mg} / \mathrm{L}(\mathbf{O})$, $100(\square), 200(\Delta), 300(\diamond) \mathrm{mg} / \mathrm{L}$ of ethylene glycol as a supplemental carbon source. Initial concentration of 1,4-dioxane was $1,000 \mathrm{mg} / \mathrm{L}$ 1,4-dioxane. Error bars indicate the standard deviations of three replicates.

\subsubsection{Tetrahydrofuran}

미생물컨소시엄 CDIK-3 배양에서 tetrahydrofuran의 첨가 에 따른 생장과 1,4-dioxane 분해에 미치는 영향을 조사하였 다(Fig.9). Tetrahydrofuran이 첨가된 것과 첨가되지 않은 것 에 비교하여 뚜렷한 차이를 나타내었다. CDIK-3의 생장은 첨가된 tetrahydrofuran 농도가 증가할수록 높은 생장률을 나 타내었다. 1,4-Dioxane 분해는 $50 \mathrm{mg} / \mathrm{L}$ tetrahydrofuran의 경 우, 120 시간 이내에 완전히 분해되어, 첨가하지 않은 것보다 분해능이 크게 향상되었다. $100-200 \mathrm{mg} / \mathrm{L}$ tetrahydrofuran 첨 가에서도 각각 132 시간 이내 완전 분해되면서 미첨가된 것과 비교하여 분해능이 향상되었지만, 농도에 따른 1,4-dioxane 분 해는 거의 유사하였다. 몇몇 연구에서 미생물 배양에 부가탄 소원으로 tetrahydrofuran의 첨가가 1,4-dioxane의 분해에 미치 는 영향에 대하여 발표된 바 있는데, 미첨가된 경우와 비교하 여 Rhodanobacter AYS5에서 약 30\%, ${ }^{20)}$ 그리고 Amycolata sp. $\mathrm{CB} 1190$ 에서 약 $40 \%{ }^{23}$ 의 1,4-dioxane의 분해가 각각 향상되 었다는 결과가 보고되었다. Masuda 등 ${ }^{29)}$ 은 Pseudonocardia sp. strain ENV478에서 tetrahydrofuran monooxygenase $(\mathrm{thm})$ 를 확인하였으며, 배양에서 tetrahydrofuran의 농도가 증가함 에 따라 thm 유전자가 유도됨을 보고하였다. Tetrahydrofuran 은 세균을 빠르게 생장시키며 공동대사(co-metabolism) 방식 으로 1,4-dioxane을 분해할 수 있는 것으로 알려져 있다. ${ }^{30}$ Zenker 등 ${ }^{24)}$ 은 tetrahydrofuran의 존재 하에서 혼합배양의 공
동대사에 의해 $200 \mathrm{mg} / \mathrm{L}$ 의 1,4-dioxane을 약 12 일 이내 완전 분해한 결과를 보고하였다. 이들 연구와 비교하였을 때, 본 연 구에서 이용한 미생물컨소시엄 CDIK-3에서도 유사한 결과를 보여주었는데, 이는 tetrahydrofuran이 1,4-dioxane을 제거하는 데 훌륭한 부가탄소원이 될 수 있다고 생각된다.

1,4-Dioxane은 고리형 에테르 화합물로서 다양한 산업에 서 널리 사용되며, 이 화합물이 포함된 산업폐수는 하천, 호 수, 지하수 등의 수계를 오염시키고 있다. 현재 1,4-dioxane 의 처리는 화학적 처리에 의존하고 있지만, 처리 비용 및 2 차 오염의 문제가 되고 있어, 이들 문제를 해결하기 위한 방 법으로 미생물학적 처리의 가능성을 연구하였다. 본 연구에 서 사용된 미생물컨소시엄 CDIK-3에 의한 1,4-dioxane의 농 도는 지금까지 보고된 결과들과 비교하여 현저하게 높은 것 으로 조사되었으며, 여러 가지 물리화학적 요인의 조절이나 적절한 부가탄소원 및 질소원의 첨가에 의해 1,4-dioxane의 분해가 증진될 수 있음이 확인되었다. 향후 연구는 미생물컨 소시엄 CDIK-3을 이용하여 1,4-dioxane이 포함된 산업폐수 의 효율적인 처리와 현장 적용, 그리고 분리된 단일 균주들 의 특성을 규명으로 방향으로 진행될 것이다.

\section{4. 결 론}

미생물컨소시엄 CDIK-3의 생장과 1,4-dioxane의 분해에 미치는 여러 가지 물리화학적 환경요인에 대한 결론은 다음 


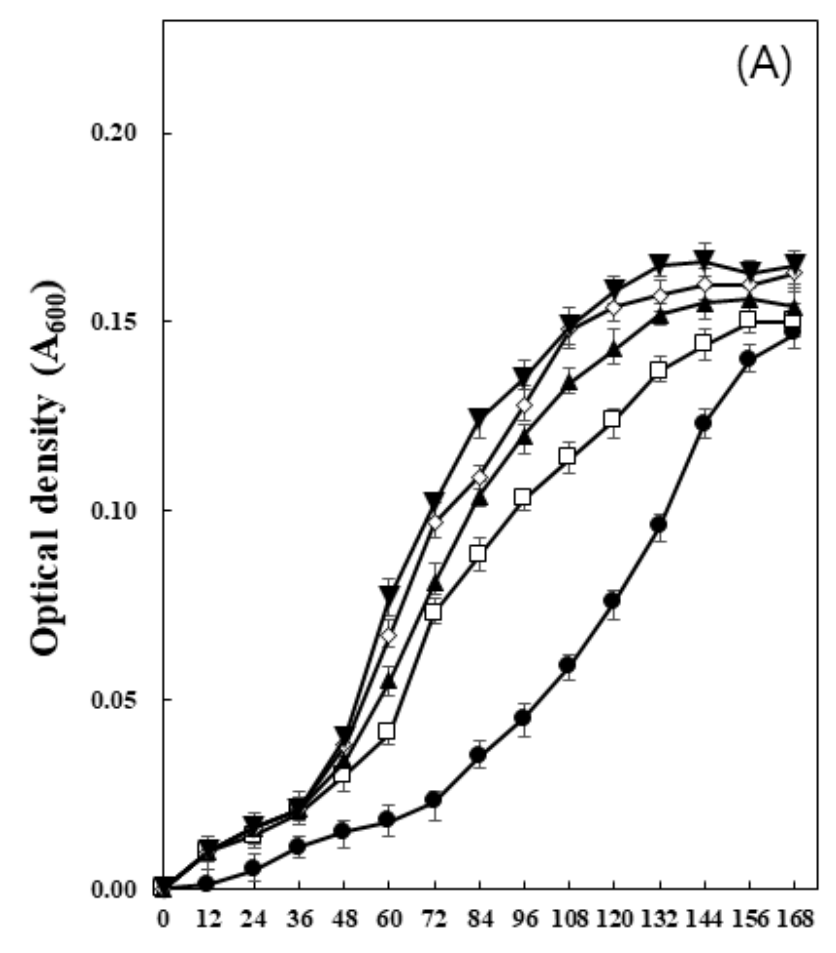

Time (h)

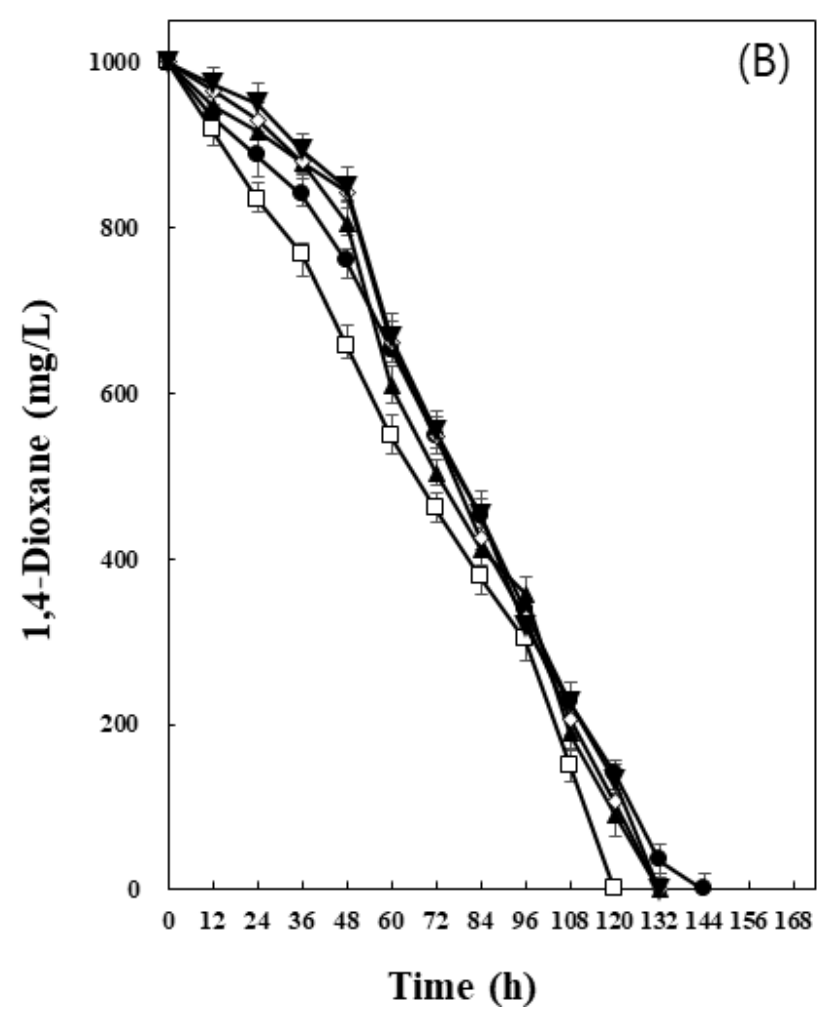

Fig. 9. Growth of microbial consortium CDIK-3 (A) and the degradation of 1,4-dioxane (B) in the presence of $0 \mathrm{mg} / \mathrm{L} \mathrm{(O)}, 50$ $(\square), 100(\mathbf{\Delta}), 150(\diamond), 200(\nabla) \mathrm{mg} / \mathrm{L}$ of tetrahydrofuran as a supplemental carbon source. Initial concentration of 1,4-dioxane was $1,000 \mathrm{mg} / \mathrm{L} \mathrm{1,4-dioxane.} \mathrm{Error} \mathrm{bars} \mathrm{indicate} \mathrm{the} \mathrm{standard} \mathrm{deviations} \mathrm{of} \mathrm{three} \mathrm{replicates.}$

과 같다:

1) 1,4-Dioxane의 초기 농도 $(250-1,500 \mathrm{mg} / \mathrm{L})$ 가 증가함에 따라 생장도 증가하였으며, $1,000 \mathrm{mg} / \mathrm{L}$ 의 1,4-dioxane은 168 시간 이내에 완전히 분해되었다. 그러나 1,4-dioxane의 농도 가 $1,250 \mathrm{mg} / \mathrm{L}$ 와 $1,500 \mathrm{mg} / \mathrm{L}$ 로 증가함에 따라, 주어진 배양 기간인 168 시간 동안에 각각 $80 \%$ 와 $67 \%$ 의 부분적인 분해 가 진행되었다.

2) 초기 $\mathrm{pH} 8.0$ 에서 $1,000 \mathrm{mg} / \mathrm{L}$ 의 1,4-dioxane은 144시 간 이내에 완전분해되었으며, 최대 생장을 보여주었다. $\mathrm{pH}$ 7.0 에서도 동일 농도의 1,4-dioxane은 168 시간에서 완전분 해되었으나, $\mathrm{pH}$ 6.0과 9.0 에서는 약 $90 \%$ 로 분해가 저조하 였다.

$3)$ 배양 온도 $\left(20-35^{\circ} \mathrm{C}\right)$ 조절에 따른 1,4-dioxane 분해는 $30^{\circ} \mathrm{C}$ 가 최적 온도로 확인되었으며, 156 시간 이내에 $1,000 \mathrm{mg} / \mathrm{L}$ 의 1,4-dioxane이 완전히 분해되었다.

4) 부가탄소원으로서 glucose $(10-50 \mathrm{mg} / \mathrm{L})$ 를 첨가한 경 우에, CDIK-3의 생장은 첨가된 glucose 농도에 비례하였 으며, $1,000 \mathrm{mg} / \mathrm{L}$ 의 1,4-dioxane이 132 시간 이내에 완전히 분해되었다.

5) Yeast extract 농도(10-50 mg/L)가 증가함에 따라 CDIK-3 는 급격히 생장하였으며, $50 \mathrm{mg} / \mathrm{L}$ 가 첨가된 경우에 1,000 $\mathrm{mg} / \mathrm{L}$ 의 1,4-dioxane이 120 시간 이내에 완전히 분해되었다.

6) $100 \mathrm{mg} / \mathrm{L}$ ethylene glycol이 첨가되었을 때, $1,000 \mathrm{mg} / \mathrm{L}$
의 1,4-dioxane이 120 시간 이내에 완전히 분해되었으나, 첨가 농도(100-300 mg/L)가 증가함에 따라 1,4-dioxane 분해는 지 연되었다.

7) $50 \mathrm{mg} / \mathrm{L}$ 의 tetrahydrofuran이 첨가되었을 때, 1,000 $\mathrm{mg} / \mathrm{L}$ 의 1,4-dioxane은 120 시간 이내에 완전히 분해되어 첨 가하지 않은 것보다 분해능이 향상되었으나, 농도 증가 $(50-100 \mathrm{mg} / \mathrm{L})$ 에 따른 분해능은 거의 유사하였다. 이들 결 과에 근거한 다양한 환경요인들을 최적화시킴으로써 산업 폐수에 포함된 1,4-dioxane을 미생물을 이용하여 효율적으 로 제거할 수 있을 것으로 판단된다.

\section{Acknowledgement}

본 연구는 순천향대학교 학술연구비지원사업의 일부지원 으로 수행되었음.

\section{References}

1. Ministry of Environment, Industrial wastewater occurrence and treatment, Sejongsi, Korea(2019).

2. R. H. Anderson, J. K. Anderson, P. A. Bower, Co-occurrence of 1,4-dioxane with trichloroethylene in chlorinated solvent groundwater plumes at US Air Force installations: fact or fiction, Integr. Environ. Assess. Manage., 8(4), 731-737 
(2012).

3. U.S. Department of Health and Human Services, Report on Carcinogens, 14th ed., Washington, D.C., USA(2016).

4. ATSDR, Toxicological Profile for 1,4-Dioxane, Agency for Toxic Substances and Disease Registry, Atlanta, USA(2012).

5. U.S. EPA, Treatment Technologies for 1,4-Dioxane: Fundamentals and Field Applications, United States Environmental Protection Agency, Washington, D.C., USA (2006).

6. A. V. Popoola, Mechanism of the reaction involving the formation of dioxane byproduct during the production of poly (ethylene terephthalate), J. Appl. Polym. Sci., 43(10), 1875-1877(1991).

7. M. J. Zenker, R. C. Borden, M. A. Barlaz, Occurrence and treatment of 1,4-dioxane in aqueous environments, Environ. Eng. Sci., 20(5), 423-432(2003).

8. U.S. EPA, Treatment Technologies for 1,4-Dioxane: Fundamentals and Field Applications, EPA 542-R-06-009, Washington, D.C., USA(2006).

9. T. H. Han, J. S. Han, M. H. So, J. W. Seo, C. M. Ahn, D. H. Min, Y. S. Yoo, D. K. Cha, C. G. Kim, The removal of 1,4-dioxane from polyester manufacturing process wastewater using an up-flow biological aerated filter (UBAF) packed with tire chips, J. Environ. Sci. Health, Part A, 47(1), 117-129(2012).

10. B. J. Kim, S. W. Han, J. Y. Park, S. H. Kim, J. Y. Kim, Distribution characteristics 1,4-dioxane and perchlorates of in Nakdong river, J. Korean Soc. Environ. Eng., 31(6), 409-411(2009).

11. National Toxicology Program, Bioassay of 1,4-dioxane for possible carcinogenicity, Natl. Cancer Inst. Carcinog. Tech. Rep. Ser., 80, 1-123(1978).

12. National Industrial Chemicals Notification and Assessment Sheme (NICNAS), 1,4-Dioxane Priority Existing Chemical No. 7. Sydney, Australia(1998).

13. R. Andreozzi, V. Caprio, A. Insola, R. Marotta, Advanced oxidation processes (AOP) for water purification and recovery, Catal. Today, 53(1), 51-59(1999).

14. C. D. Adams, P. A. Scanlan, N. D. Secrist, Oxidation and biodegradability enhancement of 1,4-dioxane using hydrogen peroxide and ozone, Environ. Sci. Technol., 28(11), 1812-1818(1994).

15. J. D. Park, J. H. Suh, H. S. Lee, A study on the degradation characteristics of 1,4-dioxane at different initial $\mathrm{H}_{2} \mathrm{O}_{2}$ concentration with advanced oxidation process using ozone and hydrogen peroxide, J. Korean Soc. Environ. Eng., 27(10), 1108-1113(2005).

16. H. S. Son, S. B. Choi, E. Khan, K. D. Zoh, The contribution of $\mathrm{OH}$ radical and the effect of adding oxidants on the sonolytic degradation of 1,4-dioxane, J. Korean Soc. Environ. Eng., 27(6), 642-650(2005).

17. R. E. Parales, J. E. Adamus, N. White, H. D. May, Degradation of 1,4-dioxane by an actinomycete in pure culture, Appl. Environ. Microbiol, 60(12), 4527-4530(1994).
18. Y. M. Kim, J. R. Jeon, K. Murugesan, E. J. Kim, Y. S. Chang, Biodegradation of 1,4-dioxane and transformation of related cyclic compounds by a newly isolated Mycobacterium sp. PH-06, Biodegradation, 20(4), 511-519(2009).

19. K. Nakamiya, S. Hashimoto, H. Ito, J. S. Edmonds, M. Morita, Degradation of 1,4-dioxane and cyclic ethers by an isolated fungus, Appl. Environ. Microbiol., 71(3), 1254-1258 (2005).

20. A. Pugazhendi, J. R. Banu, J. Dhavamani, I. T. Yeom, Biodegradation of 1,4-dioxane by Rhodanobacter AYS5 and the role of additional substrates, Ann. Microbiol, 65, 2201-2208(2015).

21. B. Sun, K. Ko, J. A. Ramsay, Biodegradation of 1,4-dioxane by a Flavobacterium, Biodegradation, 22(3), 651-659(2011).

22. D. Inoue, T. Tsunoda, N. Yamamoto, M. Ike, K. Sei, 1,4-Dioxane degradation characteristics of Rhodococcus aetherivorans JCM 14343, Biodegradation, 29(3), 301-310 (2018).

23. S. L. Kelley, E. W. Aitchison, M. Deshpande, J. L. Schnoor, P. J. J. Alvarez, Biodegradation of 1,4-dioxane in planted and unplanted soil: effect of bioaugmentation with Amycolata sp. CB1190, Water Res., 35(16), 3791-3800(2001).

24. M. J. Zenker, R. C. Borden, M. A. Barlaz, Mineralization of 1,4-dioxane in the presence of a structural analog, Biodegradation, 11(4), 239-246(2000).

25. Y. He, J. Mathieu, M. L. B. da Silva, M. Li, P. J. J. Alvarez, 1,4-Dioxane-degrading consortia can be enriched from uncontaminated soils: prevalence of Mycobacterium and soluble di-iron monooxygenase genes, Microb. Biotechnol., 11(1), 189-198(2018).

26. T. R. Tusher, T. Shimizu, C. Inoue, M. F. Chien, Enrichment and analysis of stable 1,4-dioxane degrading microbial consortia consisting of novel dioxane-degraders, Microorganisms, 8(1), 50(2020).

27. Y. Zhong, T. Luan, L. Lin, H. Liu, N. F. Y. Tam, Production of metabolites in the biodegradation of phenanthrene, fluoranthene and pyrene by the mixed culture of Mycobacterium sp. and Sphingomonas sp., Bioresour. Technol., 102(3), 2965-2972(2011).

28. S. Scalia, Reversed-phase high-performance liquid chromatographic method for the assay of 1,4-dioxane in sulphated polyoxyethylene alcohol surfactants, J. Pharm. Biomed. Anal., 8(8-12), 867-870(1990).

29. H. Masuda, K. McClay, R. J. Steffan, G. J. Zylstra, Biodegradation of tetrahydrofuran and 1,4-dioxane by soluble diiron monooxygenase in Pseudonocardia sp. strain ENV478, J. Mol. Microbiol. Biotechnol., 22(5), 312-316(2012).

30. S. Mahendra, L. Alvarez-Cohen, Kinetics of 1,4-dioxane biodegradation by monooxygenase-expressing bacteria, Environ. Sci. Technol., 40(17), 5435-5442(2006). 
Moon-Seop Choi et al.

\section{Authors}

\section{Moon-Seop Choi}

Department of Life Science and Biotechnology, Soonchunhyang University, CDI Co., Ltd., Ph.D. Student, ORCiD(1) 0000-00029492-4444

\section{Ki-Seung Choi}

CDI Co., Ltd., Senior Managing Director

\section{Kye-Heon Oh}

Department of Life Science and Biotechnology, Soonchunhyang University, Professor, ORCID(10) 0000-0002-9234-0891 